\title{
Profil Miskonsepsi Mahasiswa Calon Guru Fisika Ditinjau Dari Berbagai Representasi Pada Materi Gerak Lurus Dan Gerak Parabola
}

\author{
Ahmad Busyairi", Muhammad Zuhdi \\ Program Studi Pendidikan Fisika, Universitas Mataram \\ *Email: ahmad.busyairi@unram.ac.id
}

Received: 6 Februari 2020;

Accepted: 20 April 2020;

Published: 24 April 2020

DOI: http://dx.doi.org/10.29303/jpft.v6i1.1683

\begin{abstract}
Misconceptions are one of the problems that often occur in education. This objected aims to identify misconceptions of pre-service physics teachers' in motion concept from various representations. The method used in this research is descriptive method. A total of 40 pre-service physics teachers' at a university in the city of Mataram were involved in this study. The instrument used in the study was a three tier test with open reasons. The reasons have been made to be open aims so that pre-service physics teachers' are more free to describe the understanding that is in their cognitive structure. A total of 15 test items used in this study. The questions are classified into three types of representations namely; verbal, figural, and graphics. The results showed that 67\% of pre-service physics teachers have misconceptions on the concept of linier motion, $53 \%$ of misconceptions on the concept of vertical motion, and $57 \%$ of misconceptions on the concept of parabolic motion. The result shows that $61 \%$ of pre-service physics teachers' have misconceptions on verbal type questions, 59\% of misconceptions on figural type, and $61 \%$ misconceptions on graphic type.
\end{abstract}

Keywords: conception; misconception; multiple representation; parabolic motion

\section{PENDAHULUAN}

Salah satu masalah yang sering dijumpai dalam dunia pendidikan khususnya pada mata pelajaran fisika adalah adanya miskonsepsi pada siswa. Miskonsepsi merupakan suatu istilah untuk menunjukkan adanya perbedaan pemikiran antara konsep yang dimiliki siswa dengan konsep yang ditetapkan ahli (Suparno \& Paul 2005). Senada dengan pernyataan tersebut, Hikmawati \& Sutrio (2019) menjelaskan bahwa miskonsepsi merupakan istilah untuk menunjukkan keadaan dimana seseorang meyakini konsep yang dimilikinya sudah benar namun pada kenyataannya konsep tersebut salah menurut ketetapan para ahli. Faktor keyakinan inilah yang membedakan siswa yang mengalami miskonsepsi dan siswa yang tidak paham konsep.

Berdasarkan hasil studi pustaka memperlihatkan bahwa $66,0 \%$ siswa mengalami miskonsepsi pada materi hukum Newton (Kaniawati et al. 2019). Sebanyak
39,9\% siswa mengalami miskonsepsi pada konsep listrik dinamis (Ismail et al. 2015). Pada materi cahaya, sebanyak $26,2 \%$ siswa mengalami miskonsepsi (Wahyuni et al. 2018). Pada materi suhu dan kalor, $51,27 \%$ mengalami miskonsepsi (Lestari et al. 2015) Begitu juga pada materi gerak lurus, 80,11\% siswa mengalami miskonsepsi (Yolanda, 2017). Dari beberapa hasil penelitian tersebut memperlihatkan bahwa, siswa mengalami miskonsepsi hampir pada semua materi fisika.

Secara umum miskonsepsi pada siswa dapat disebabkan oleh banyak faktor salah satunya adalah faktor guru yang mengajar di kelas (Barke et al. 2009). Kesalahan guru dalam mengajar, konsepsi guru yang salah, dan pemahaman guru yang tidak memadai dapat menimbulkan miskonsepsi pada siswa. Miskonsepsi yang disebabkan oleh kesalahan guru biasanya agak sulit dibenahi karena siswa merasa yakin bahawa konsep yang diberikan guru mereka sudah benar. 
Dengan demikian, sebaiknya guru atau calon guru harus benar-benar menguasai materi yang akan mereka ajarkan di kelas.

Peran guru yang begitu besar terhadap pembentukan konsepsi siswa nampaknya perlu menjadi perhatian khusus. Perhatian yang dimaksudkan di sini terkait dengan konsepsi guru, apakah konsepsi yang dimiliki guru atau calon guru sudah benar atau justru malah mengalami miskonsepsi. Oleh karena itu, perlu kiranya dilakukan identifikasi terkait konsepsi yang dimiliki calon guru sebelum mereka benar-benar menjadi guru di sekolah.

Penelian ini bertujuan untuk melihat profil miskonsepsi mahasiswa calon guru fisika khusunya pada materi gerak lurus dan gerak parabola. Materi gerak lurus dan gerak parabola dipilih karena pada materi inilah siswa paling banyak mengalami miskonsepsi (Yolanda, 2017). Peneliti ingin mengetahui apakah setelah siswa menjadi mahasiswa dan mendalami konsep fisika di Universitas masih mengalami miskonsepsi atau tidak. Jika ditemukan ternyata mahasiswa masih banyak mengalami miskonsepsi, maka ini mengindikasikan bahwa metode, strategi, pendekatan, atau model pembelajaran yang selama ini digunakan dosen masih belum mampu mereduksi miskonsepsi mahasiswa.

Miskonsepsi mahasiswa pada peneltiian ini akan diidentifikasi dari berbegai representasi. Representasi yang dimaksud di sini dapat berupa kata-kata, gambar, dan grafik. Hal ini betujuan agar diperoleh informasi yang lebih lengkap yaitu; pada konsep apa saja mahasiswa mengalami miskonsepsi dan pada jenis representasi apa saja mahasiswa paling banyak mengalami miskonsepsi. Informasi ini selanjutnya dapat digunakan sebagai landasan dalam menentukan pendekatan, metode, strategi, dan model pembelajaran bagi dosen sebelum mengajar di kelas.

\section{METODE PENELITIAN}

Metode yang digunakan dalam penelitian ini adalah metode penelitian deskriptif. Penelitian deskriptif merupakan penelitian untuk memberikan uraian mengenai gejala, fenomena, atau fakta yang diteliti dengan mendeskripsikan tentang nilai variabel tanpa bermaksud membandingkan (Musfiqon, 2012). Tujuan utama dari penelitian deskriptif adalah untuk membuat deskripsi atau gambaran secara sistematis dan akurat mengenai fakta-fakta yang diselidiki.

Sampel terdiri dari 40 mahasiswa calon guru fisika pada salah satu universitas yang ada di kota Mataram. Instrumen yang digunakan dalam penelitian ini berupa tes tiga tingkat (three tier test) dalam bentuk tes multiple choice dengan alasan terbuka. Alasan dalam instrumen tes ini dibuat terbuka bertujuan agar siswa lebih leluasa mendeskripsikan pemahaman yang ada dalam struktur kognitif mereka. Sebanyak 15 item soal digunakan dalam penelitian ini. Soal-soal tersebut diklasifikasikan ke dalam tiga bentuk representasi yaitu verbal, figural, dan grafik. Hal ini bertujuan untuk mengetahui distribusi miskonsepsi calon guru fisika pada tiap-tiap representasi khususnya pada materi gerak lurus dan gerak parabola. Sebelum digunakan, instrumen tes terlebih dahulu divalidasi oleh ahli. Validasi ini bertujuan untuk melihat kesesuaian antara isi instrumen dengan materi yang sudah diajarkan, kesesuaian soal dan jawaban, serta kesesuaian tata bahasa.

Data hasil tes kemudian dianalisis dan dikategorikan untuk mengetahui konsepsi mahasiswa. Data yang sudah dikategorikan kemudian dianalisis menggunakan statistik deskriptif dengan menghitung persentase jumlah mahasiswa yang mengalami miskonsepsi, paham konsep, dan tidak paham konsep pada tiap-tiap representasi. Berikut adalah pedomen pengkategorian 
konsepsi mahasiswa dengan menggunakan tes tiga tingkat (three tier test) (Arslan, Cigdemoglu, \& Moseley, 2012).

Tabel 1. Pengkategorian konsepsi mahasiswa dengan menggunakan tes tiga tingkat (Arslan, et al. 2012)

\begin{tabular}{cccccccc}
\hline Jawaban & Kode & Alasan & Kode & Keyakinan & Kode & Kategori & Kode \\
\hline Benar & B & Benar & B & Yakin & Y & Paham Konsep & PK \\
\hline Benar & B & Salah & S & Yakin & Y & Miskonsepsi & M \\
\hline Salah & S & Benar & B & Yakin & Y & Miskonsepsi & M \\
\hline Salah & S & Salah & S & Yakin & Y & Miskonsepsi & M \\
\hline Benar & B & Benar & B & Tidak Yakin & TY & Menebak & TB \\
\hline Benar & B & Salah & S & Tidak Yakin & TY & Tidak Paham Konsep & TPK \\
\hline Salah & S & Benar & B & Tidak Yakin & TY & Tidak Paham Konsep & TPK \\
\hline Salah & S & Salah & S & Tidak Yakin & TY & Tidak Paham Konsep & TPK \\
\hline
\end{tabular}

\section{HASIL DAN PEMBAHASAN}

Hasil analisis data memperlihatkan bahwa persentase mahasiswa calon guru fisika yang mengalami miskonsepsi, tidak paham konsep, dan paham konsep pada tiaptiap sub-materi gerak yaitu sebagai berikut.

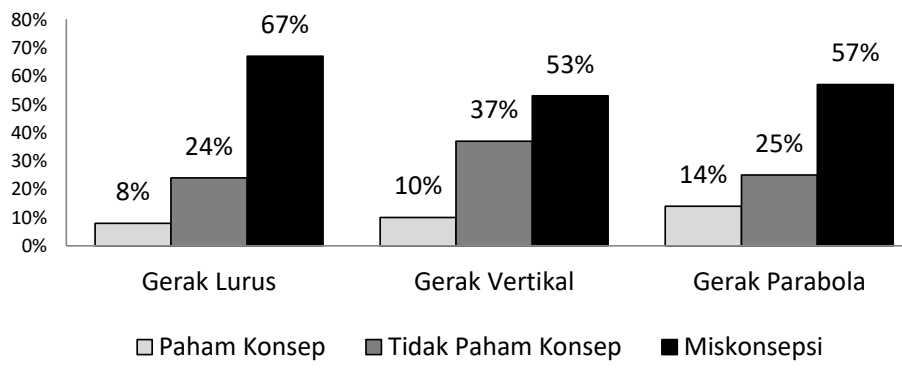

Gambar 1. Profil konsepsi mahasiswa berdasarkan sub-materi gerak

Grafik di atas memperlihatkan bahwa sebanyak $67 \%$ mahasiswa mengalami miskonsepsi pada materi gerak lurus, $57 \%$ mengalami miskonsepi pada materi gerak parabola, dan $53 \%$ mengalami miskonsepsi pada materi gerak vertikal. Selanjutnya, untuk mengetahui pada jenis atau tipe represenasi apa saja mahasiswa paling banyak mengalami miskonsepsi, berikut disajikan grafik persentase mahasiswa berdasarkan tipe representasi.

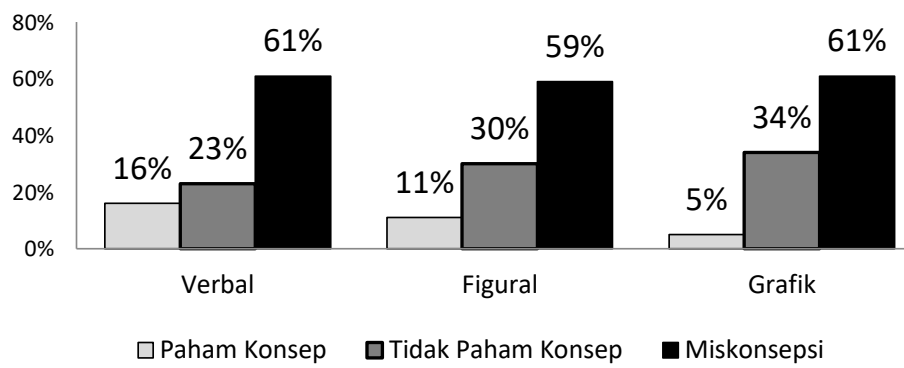

Gambar 2. Profil konsepsi mahasiswa jika ditinjau dari berbagai representasi

Grafik di atas memperlihatkan bahwa sebanyak $61 \%$ mahasiswa mengalami miskonsepsi pada konsep yang disajikan dalam bentuk verbal dan konsep yang disajikan dalam bentuk grafik sedangkan pada konsep yang disajikan dalam bentuk 
figural atau gambar, jumlah mahasiswa yang mengalami miskonsepsi lebih sedikit yaitu sebanyak 59\%. Untuk mengetahui profil miskonsepsi mahasiswa secara lebih mendalam beserta penyebabnya, peneliti akan mangenalisis dan mengidentifikasi letak miskonsepsi berdasarkan pola jawaban mahasiswa dari tiap-tiap butir soal yang diberikan.

Dalam materi kinematika gerak lurus terdapat beberapa miskonsepsi yang dialami mahasiswa. Kita mulai dari konsep kecepatan sebagai besaran vektor. Sebanyak 25\% mahasiswa beranggapan bahwa ketika benda mula-mula bergerak ke kanan kemudian diperlambat hingga akhirnya berhenti, maka selama benda mengalami perlambatan kecepatan benda tersebut negatif (berlawanan dengan arah kecepatan semula). Konsep yang benar yaitu ketika benda diperlambat maka kecepatan benda tersebut berkurang (bukan negatif) hingga akhirnya berhenti (kecepatan nol) (Giancoli, 2001; Tipler, \& Mosca, 2008; Gordon et al. 2010).

Mahasiswa juga kesulitan ketika konsep kecepatan ditampilkan dalam bentuk gambar. Ketika mereka diberi gambar jejak posisi dua buah benda yang sedang bergerak lurus ke kanan.

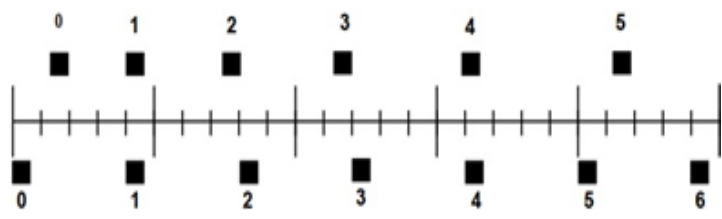

Gambar 3. Posisi benda tiap interval satu detik

Kemudian mereka diintruksikan untuk menentukan kapan kedua benda memiliki kecepatan yang sama. Sebanyak 60\% mahasiswa mengalami miskonsepsi pada kasus ini. Mereka beranggapan bahwa benda memiliki kecepatan yang sama ketika posisi kedua benda sama atau sejajar (pada detik ke-1 dan detik ke-4). Padahal dua buah benda dikatakan memiliki besar kecepatan yang sama ketika besar perubahan posisi benda tersebut sama tiap satuan waktu (Giancoli, 2001; Rokhmat et al. 2019). Pada kasus ini, yang memungkinkan kedua benda memiliki kecepatan yang sama yaitu ketika benda berada pada interval waktu antara detik ke-2 hingga detik ke-3 karena besar perubahan posisi kedua benda pada saat itu sama tiap satuan waktu.

Selanjutnya konsep kecepatan ditampilkan dalam bentuk grafik. Masih banyak mahasiswa yang mengalami miskonsepsi ketika menjawab soal dalam bentuk grafik kecepatan terhadap waktu.

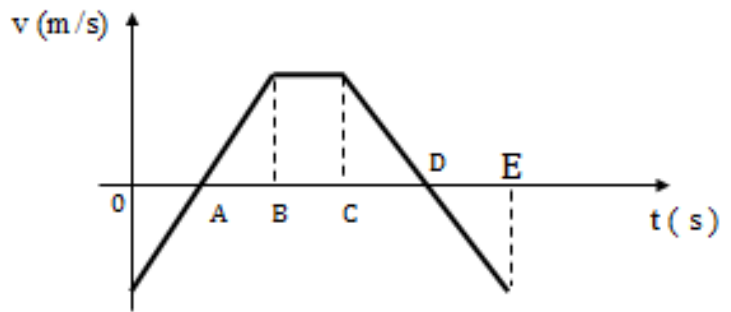

Gambar 4. Grafik kecepatan terhadap fungsi waktu

Dari grafik di atas, mahasiswa ditugaskan menentukan pada selang waktu berapa benda mengalami perlambatan. Sebanyak 70\% mahasiswa miskonsepsi pada kasus ini. Mereka beranggapan bahwa benda mengalami perlambatan pada selang waktu dari $\mathrm{C}$ ke E. Alasannya adalah karena grafinya mengalami penurunan. Hal ini memperlihatkan bahwa di dalam struktur kognitif mahasiswa setiap grafik yang menurun adalah grafik perlambatan dan begitu juga sebaliknya, setiap grafik yang menanjak adalah grafik percepatan (Hikmawati \& Sutrio, 2019). Padahal pada kenyataannya pada selang waktu dari C ke D benda mengalami perlambatan kemudian pada selang waktu berikutnya dari D ke E benda mengalami percepatan. Sebagai informasi, benda mengalami perlambatan pada grafik di atas adalah pada interval waktu dari 0 ke A dan dari C ke D. 
Soal berbentuk grafik juga diberikan kepada mahasiswa untuk mengetahui konsepi mereka terkait kecepatan sebagai besaran vektor. Mereka ditugaskan untuk menentukan grafik kecepatan terhadap waktu dari sebuah benda yang dilempar vertikal ke atas kemudian kembali lagi ke titik pelemparannya. (a)

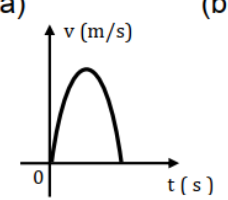

(d)

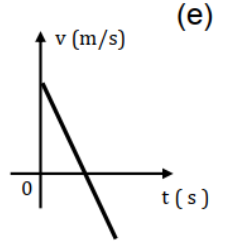

(e)

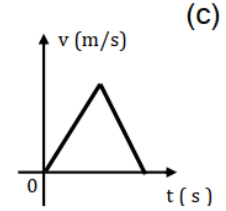

(c)
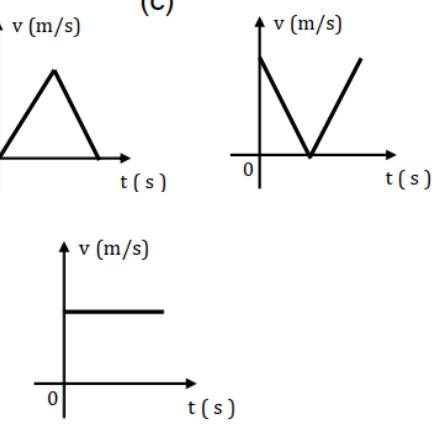

Gambar 5. Grafik kecepatan terhadap fungsi waktu

Pada kasus ini, sebanyak $65 \%$ mahasiswa mengalami miskonsepsi dan sisanya 35\% tidak paham konsep. Sebanyak $65 \%$ mahasiswa menjawab (a) dengan alasan bahwa bentuk lintasan benda yang dilempar vertikal ke atas kemudian kembali lagi ke titik pelemparannya sama seperti yang ditunjukkan grafik. Sebanyak 25\% dari mereka menjawab (c) dengan alasan bahwa benda yang dilempar vertikal ke atas kemudian kembali lagi ke titik pelemparan mula-mula mengalami gerak diperlambat kemudian dipercepat setelah melewati titik tertinggi. Alasan ini cukup benar, namun mereka lupa bahwa kecepatan merupakan besaran vektor yang besar dan arahnya bisa mengalami perubahan. Keselahan dalam menentukan arah kecepatan membuat mahasiswa salah dalam memilih grafik. Pada kasus ini grafik yang paling benar adalah grafik (d). Grafik tersebut menunjukkan bahwa benda mula-mula diperlambat kemudian setelah melewati titik tertinggi benda dipercepat disertai dengan perubahan arah kecepatan (ke bawah atau ke arah sumbu y-) (Rokhmat et al. 2019).
Selain konsep kecepatan, mahasiswa juga mengalami miskonsepsi pada konsep percepatan sebagai besaran vektor. Dari hasil analisis data memperlihatkan bahwa, sebanyak $65 \%$ mahasiswa yakin bahwa benda yang dilempar vertikal ke atas memiliki percepatan nol saat berada pada titik tertinggi hingga pada akhirnya percepatan benda tersebut berubah arah mengikuti arah gerak benda. Hasil penelitian ini sama dengan hasil penelitian Novitasati (2016) yaitu siswa beranggapan bahwa percepatan benda pada saat mencapai titik tertinggi adalah nol. Padahal pada kenyataanya percepatan benda pada kasus ini selalu konstan dan arahnya selalu menuju pusat bumi. Anggapan ini mengindikasikan bahawa mahasiswa belum benar-benar bisa membedakan konsep kecepatan dan percepatan. Mereka beranggapan bahwa ketika benda diam maka percepatan benda tersebut pasti nol padahal yang bernilai nol adalah kecepatannya.

Untuk mengetahui pemahaman mahasiswa terkait definisi percepatan, selanjutnya konsep percepatan ditampilkan dalam bentuk gambar. Ketika mereka diberi gambar posisi dua buah balok yang sedang bergerak lurus ke kanan (posisi balok digambarkan tiap interval satu detik).

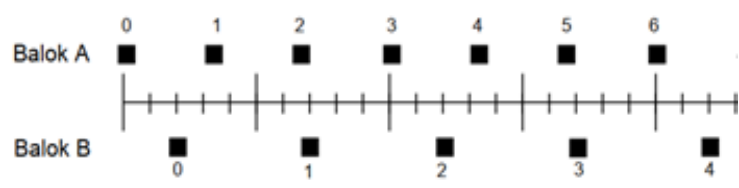

Gambar 6. Posisi benda tiap interval satu detik

Kemudian mereka diintruksikan untuk menentukan percepatan dari masing-masing balok. Sebanyak 55\% mahasiswa miskonsepsi pada kasus ini dan $40 \%$ mahasiswa masih tidak paham konsep. Mereka beranggapan bahwa percepatan balok B lebih besar daripada percepatan balok A. Padahal pada kenyataanya kedua balok sedang bergerak lurus beraturan (berGLB). Artinya kecepatan balok konstan 
sehingga kedua balok sama-sama tidak memiliki percepatan (percepatan nol).

Selanjutnya konsep percepatan ditampilkan dalam bentuk grafik. Mahasiswa ditugaskan untuk menentukan grafik percepatan terhap waktu dari sebuah benda yang dilempar vertikal ke atas kemudian kembali lagi ke titik pelemparannya.
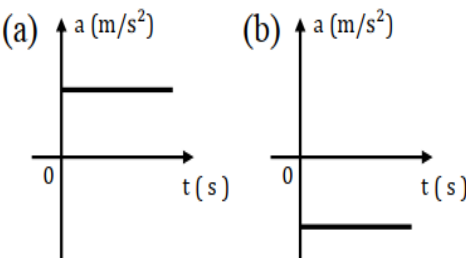

(c)

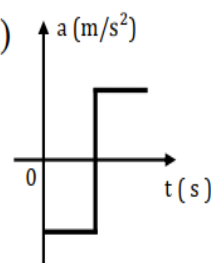

(d)

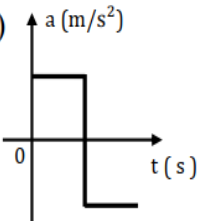

(e) $\uparrow^{a\left(m / s^{2}\right)}$

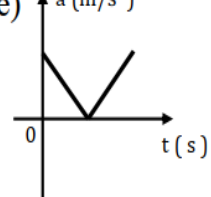

Gambar 7. Grafik percepatan terhadap waktu

Pada kasus ini, sebanyak 30\% mahasiswa mengalami miskonsepsi, 45\% mahasiswa tidak paham konsep dan 25\% dari mereka paham konsep. Mahasiswa memiliki jawaban yang beragam dalam kasus ini. Sebanyak $40 \%$ mahasiswa menjawab (d) dan (e). Mereka beranggapan bahwa gafik tersebut menunjukkan jenis gerak benda yang mula-mula diperlambat kemudian setelah melewati titik tertinggi benda tersebut dipercepat. Sebanyak 35\% dari mereka menjawab (a) dengan sebagian besar beralasan bahwa pada gerak vertikal ke atas ataupun ke bawah benda mengalami Gerak Lurus Berubah Beraturan (GLBB). Itu artinya percepatan benda tersebut konstan yaitu sama dengan percepatan gravitasi. Namun mereka lupa bahwa percepatan merupakan besaran vektor yang arahnya juga harus dipertimbangkan. Pada kasus gerak vertikal, selama tidak ada gaya luar yang bekerja pada benda, maka percepatan benda sama dengan percepatan gravitasi yang arahnya selalu ke pusat bumi (ke bawah atau sumbu y-) (Giancoli, 2001; Tipler et al. 2008; Gordon et al. 2010).

Pada soal berbentuk grafik, mahasiswa juga diuji pemahan mereka terkait cara membaca grafik posisi terhadap waktu. mereka diberikan sebuah grafik posisi benda terhadap waktu seperti pada gambar berikut.

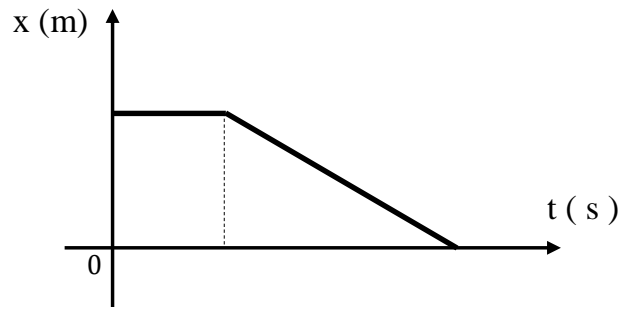

Gambar 8. Grafik posisi terhadap waktu

Mereka kemudian diintruksikan untuk menentukan jenis pergerakan benda berdasarkan grafik tersebut. Sebanyak $65 \%$ mahasiswa mengalami miskonsepsi pada kasus ini. Kebanyakan dari mereka beranggapan bahwa grafik tersebut menunjukkan pergerakan dari sebuah benda yang mula-mula bergerak dengan kecepatan konstan kemudian diperlambat hingga pada akhirnya berhenti. Hal ini memperlihatkan bahwa di dalam struktur kognitif mereka tidak bisa membedakan mana grafik kecepatan terhadap waktu, grafik posisi terhadap waktu, dan grafik percepatan terhadap waktu. Setiap grafik yang memiliki gradien sama dengan nol selalu mereka tafsirkan bahwa benda mengalami kecepatan konstan. Begitu juga setiap grafik yang menurun selalu mereka tafsirkan bahwa benda mengalami perlambatan. Hal ini harus menjadi perhatian khusus bagi dosen yang mengajar di kelas.

Pada materi gerak pada bola, masih banyak mahasiswa calon guru fisika mengalami miskonsepsi. Hal ini terlihat dari hasil jawaban mereka ketika diberi soal terkait hubungan antara jangkauan (jarak mendatar) yang ditempuh benda dengan waktu tempuh. 


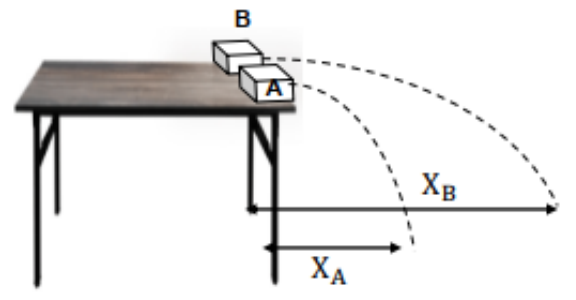

Gambar 9. Bentuk lintasan dua buah benda

Sebanyak 85\% mahasiswa mengalami miskonsepsi pada kasus ini. Mereka beranggapan bahwa balok A akan lebih dulu menyentuh lantai jika dibandingkan dengan balok B dengan alasan semakin besar jangkauan yang ditempuh benda maka semakin lama benda tersebut melayang di udara. Padahal pada kenyataanya kedua benda tersebut akan menyentuh lantai secara bersamaan karena waktu tempuh benda tidak dipengaruhi oleh jangkauan dari benda tersebut melainkan dipengaruhi oleh ketinggian benda.

Selain itu, mahasiswa juga beranggapan bahwa jika dua buah benda bergerak di atas meja licin dengan kecepatan yang sama namun dengan massa yang berbeda tiba-tiba meninggalkan meja dengan lintasan parabola maka benda yang bermassa lebih kecil akan menempuh jangkauan (jarak mendatar) yang lebih besar. Sebanyak $65 \%$ mahasiswa miskonsepsi pada kasus ini dengan jawaban yang cukup beragam yang intinya mereka beranggapan bahwa massa benda mempengaruhi jangkauan yang tempuh benda. Padahal pada kenyatannya massa benda tidak berpengaruh pada jangkauan yang dialami benda melainkan dipengaruhi oleh kecepatan awal dan ketinggian benda.

Untuk mengatahui konsepsi mahasiswa terkait komponen kecepatan pada materi gerak parabola, mahasiswa diintruksikan untuk menentukan bentuk lintasan dari sebuah benda yang jatuhkan dari pintu belakang sebuah pesawat yang sedang bergerak ke kanan dengan kecepatan konstan seperti pada Gambar 10.

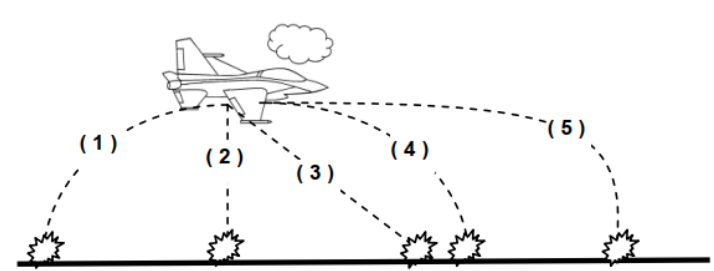

Gambar 10. Bentuk lintasan benda yang dijatuhkan dari pesawat

Sebanyak 50\% mahasiswa mengalami miskonsepsi pada kasus ini dan sisanya $25 \%$ tidak paham konsep. Sebanyak $45 \%$ mahasiswa menjawab benda bergerak seolah ke belakang karena pesawat tetap bergerak ke depan dengan kecepatan konstan seperti yang ditunjukkan pada lintasan (1). Mereka tidak tahu bahwa benda juga memiliki komponen kecepatan arah horizontal yang besar dan aranya sama dengan arah pergerakan pesawat. Sebanyak 20\% mahasiswa beranggapan bahwa benda akan jatuh tegak lurus ke bawah dan siswanya menjawab dengan jawaban selain itu. Lintasan yang paling benar dari pergerakan benda tersebut adalah lintasan (4) yang berbentuk lintasan setengah parabola.

Berdasarkan hasil analisis data di atas memperlihatkan bahwa masih banyak mahasiswa mengalami miskonsepi pada materi gerak lurus dan gerak parabola. Konsepsi yang ada dalam struktur kognitif mahasiswa masih tumpang tindih dan belum bisa membedakan konsep perpindahan, kecepatan, dan percepatan dalam semua tipe representasi (verbal, figural, dan grafik). Hal ini menunjukkan bahwa sebagian besar mahasiswa tidak memahami makna fisis dari konsep-konsep tersebut.

Walaupun dalam semua tipe representasi mengalami miskonsepsi, namun mahasiswa mengalami miskonsepsi dan tidak paham konsep paling banyak terlihat ketika mereka menjawab soal yang berkaitan dengan grafik. Hanya sebesar 5\% dari mahasiswa yang benar-benar memahami konsep kecepatan dan percepatan dalam bentuk grafik. Oleh karena itu, hal ini harus 
menjadi perhatian khusus bagi dosen yang mengajar di kelas agar para mahasiswa calon guru benar-benar dibekali dengan memahami konsep sebelum mereka benar benar menjadi guru di lapangan. Mahasiswa sebaiknya tidak hanya dilatihkan untuk menurunkan rumus (pendekatan matematis) semata malainkan mereka juga diberikan kesempatan untuk menganalisis makna fisis dari setiap rumus yang mereka turunkan. Mahasiswa juga dilatihkan membuat dan atau membaca grafik terkait konsep yang mereka pelajari. Hal ini bertujuan agar pemahan mahasiswa lebih matang dan kompleks dalam berbagai representasi.

Berdasarkan hasil penelitian dan hasil studi pustaka terkait karakteristik materi gerak lurus dan gerak parabola yang didalamnya mencakup banyak tipe permasalahan jika ditinjau dari berbagai representasi (verbal, figural, matematis, dan grafik), dirasa perlu untuk menggunakan pendekatan multirepresentasi dalam pembelajaran. Pembelajaran dengan pendekatan multirepresentasi ini cukup efektif dalam mereduksi miskonsepsi yang terjadi pada mahasiswa. Hal ini sesuai dengan hasil penelitian Suhandi dan Wibowo (2012) memperlihatkan bahwa pengguanan pendekatan multirepresentasi dalam pembelajaran memiliki efektivitas yang tergolong tinggi dalam menanamkan konsep-konsep mahasiswa. Sejalan dengan hasil penelitian tersebut, Mayer (dalam Suhandi dan Wibowo, 2012) nyatakan bahwa multiple representation can support the construction of deeper conceptual understanding.

\section{PENUTUP}

Berdasarkan hasil penelitian menunjukkan bahwa sebanyak $67 \%$ mahasiswa mengalami miskonsepi pada konsep gerak lurus, 53\% mahasiswa mengalami miskonsepsi pada konsep gerak vertikal, dan 57\% mahasiswa mengalami moskonsepsi pada materi gerak parabola. Jika ditinjau berdasarkan representasinya, sebanyak $61 \%$ miskonsepsi pada soal verbal, $59 \%$ pada soal figural, dan $61 \%$ pada soal grafik. Hasil penelitian tersebut memperlihatkan bahwa miskonsepsi yang terjadi pada mahasiswa tergolong besar pada semua konsep pada materi gerak lurus dan gerak parabola.

Pada penelitian ini, materi yang digunkan terbatas pada materi gerak lurus dan gerak parabola. Oleh karena itu, peneliti menyarankan bagi peneliti selanjutnya untuk mengidentifikasi miskonsepsi mahasiswa pada materi yang lain apakah mendapatkan hasil yang sama atau berbeda. Selain itu, peneliti juga menyarankan agar penelitian selanjutnya menggunak jenis tes lain (selain tes tiga tingkat) untuk melihat apakah mendapat hasil yang berbeda jika dibandingkan dengan ketika menggunakan tes tiga tingat (three tier test).

\section{REFERENSI}

Arslan, H. O., Cigdemoglu, C., \& Moseley, C. (2012). A Three-Tier Diagnostic Test to Assess Pre-Service Teachers' Misconceptions about Global Warming, Greenhouse Effect, Ozone Layer Depletion, and Acid Rain. International Journal of Science Education, 34 (11), 1667- 1686. DOI: 10.1080/09500693.2012.680618

Barke, H.D., Al Hazari, \& Yitbarek, S. (2009). Misconceptions in Chemistry. Addressing Perceptions in chemical Education. Berlin: Springer.

Giancoli, (2001). Fisika Dasar Jilid I (Edisi Kelima). Jakarta: Erlangga

Gordon, J. R., McGrew, R. V., \& Serway, R. A. (2010). Physics For Scientists And Engineers, Eighth Edition Volume 1. USA: Cengage Learning, Inc.

Hikmawati \& Sutrio. (2019). Miskonsepsi dalam Fisika. Selong: Garuda Ilmu. 
Ismail, I. I., Samsudin, A., Suhendi, E., \& Kaniawati, I. (2015). Diagnostik miskonsepsi melalui listrik dinamis four tier test. Prosiding Simposium Nasional Inovasi dan Pembelajaran Sains, Bandung-Indonesia. 381-384.

Kaniawati, I. (2017). Pengaruh Simulasi Komputer Terhadap Peningkatan Penguasaan Konsep ImpulsMomentum Siswa SMA. Jurnal Pembelajaran Sains, 1,(1), 24-26.

Kaniawati, I., Fratiwi, N.J., Danawan, A., Suyana, I., Samsudin, Suhendi, E. (2019). Analyzing Students' Misconceptions about Newton's Laws through Four-Tier Newtonian Test (FTNT). Journal of Turkish Science Education, 16 (1), 110-122.

Lestari, P., Rahayu, S., \& Hikmawati, H. (2017). Profil Miskonsepsi Siswa Kelas X Smkn 4 Mataram pada Materi Pokok Suhu, Kalor, dan Perpindahan Kalor. Jurnal Pendidikan Fisika dan Teknologi, 1(3), 146-153.

Musfiqon, H. M. (2012). Panduan Lengkap Metodologi Penelitian Pendidikan. Jakarta: Prestasi Pustakarya.

Rokhmat, J., Marzuki, \& Wahyudi, (2019). Fisika SMA-1a dengan pendekatan Berfikir Kausalitik. Mataram: Litpam

Suhandi, A., \& Wibowo, F. C. (2012). Pendekatan multirepresentasi dalam pembelajaran usaha-energi dan dampak terhadap pemahaman konsep mahasiswa. Jurnal Pendidikan Fisika Indonesia, 8(1). 1-7.

Suparno \& Paul. (2005). Miskonsepsi dan Perubahan Konsep dalam Pendidikan Fisika. Jakarta: Grasindo.

Tipler, P. A. \& Mosca, G. (2008). Physics for Scientists and Engineers, Sixth edition. New York: W H Freeman and Company.

Wahyuni, A.S.A., Rusdiana, D., Rustaman, N., \& Muslim. (2018). Paper Conceptions and Misconceptions of PreService Teacher about Light. International Conference on
Advanced Multidisciplinary Research (ICAMR). 227 (1), hal. 56-60.

Yolanda, Y. (2017). Remediasi Miskonsepsi Kinematika Gerak Lurus dengan Pendekatan STAD. SPEJ (Science and Physic Education Journal), 1(1), 3948. 